する期待についての講演 ${ }^{(1) \sim(10)}$ が行われた.

引き続きパネルディスカッションが行われ，熱物性研究はエ レクトロニクス, 航空宇宙, 原子力などの先端科学技術分野の みならず, 大陸移動などの地球の進化をシミュレーションする にも必要であり，生体の理解など広範な科学技術を支える基盤 技術であるとの共通認識が得られた。

10 月 24 日 (日) 〜 28 日 (木) の 5 日間にわたって, 静岡大 学工学部（浜松市）を主会場に 2004 年度日本冷凍空調学会年 次大会が開催された. 従来の学術講演会から年次大会へと改称 しての初めての大会であり, 冷凍空調機器メーカからも多くの 参加があった． 9 件のオーガナイズドセッションが企画され， 計 126 件の口頭発表が行われた. 特に熱交換器や圧縮機などの 要素機器, 自然冷媒・承蓄熱や次世代冷凍システムなどに関す るセッションに多くの講演が集まった. また特別講演として は，AIBOの開発を手がけた大梘正氏（スミダコーポレーショ ン) と, IIR (国際冷凍協会) のB2 部門前委員長でありまた ASHRAE International Journal of HVAC\&R Research の現編集長 である Radermacher 教授による講演があった。機器関連の発 表が多く，熱物性に関連する発表は OS-5「熱物性データの相 関と状態式の作成」での 10 件であったが, 冷媒の状態方程式 に関連して活発な議論が交わされた。 また学術講演以外の企画 として,「熱物性ランチセミナー」も企画され，熱物性データ の取りまとめなど, 横断的な討論が行われた.

8 月 $23 \sim 28$ 日に中国安徽省合肥市の中国科学技術大学に拉 いて第 7 回アジア熱物性会議が開催された。参加者は約 80 名で そのうち 20 名以上は日本からの参加であった。測定法, 熱分 析, 熱力学特性, 応用などのセッションが企画され熱力学, 熱 物性の広範な分野について基礎から応用までの研究成果が報告 された。

9月28日から10月1日まで, フランス, ソフィアーアンティポ リスにて国際ワークショップ「Therminic2004」が開かれた ${ }^{(11)}$. LSI などの熱問題に関わる諸問題がテーマの会議で, 2004 年で 10 回を数えた。今回の参加総数は 82 名で, 比較的小さな会議 であるが，ヨーロッパを中心にアジア，アメリカなど，ISIの 要となる地域から参加者が集まって扣り, NOKIA, BOSCH, Phillips などヨーロッパの主要メーカからは若手研究者が数多 く参加していた。 日本からの参加者は 5 名であった. 総講演数 は 54 件で口頭発表が 36 件, ポスターが 14 件, 招待講演が 4 件 であった，報告された成果はナノスケールの熱物性から実装レ ベルの熱問題まで幅広く，LSI 評価技術や冷却技術，計算機を 用いた LSI チップの熱解析など，デバイス開発に直結した研究 発表が多く見られた。特に近年のチップの高集積化に伴い，微 小領域での発熱の問題に対する関心は高い. 4 件の招待講演で は, 日本, アメリカ, ヨーロッパ (2 件)における薄膜・微小 領域の熱問題に造詣の深い研究者からそれぞれの国での最新の 技術開発の紹介があり，活発な質疑応答が行われた。

産業技術総合研究所により昨年度供給が開始された熱膨張率 標準 $\left(0 \sim 40^{\circ} \mathrm{C}\right)$ に引き続き，熱物性国家計量標準の開発が進 展し, 熱膨張率標準試料 $(300 \sim 1000 \mathrm{~K})$, 熱拡散率測定依頼試 験 $(1200 \sim 1500 \mathrm{~K})$, 粘度標準液依頼試験 $\left(-40 \sim 100^{\circ} \mathrm{C}\right)$ な どについて国際的に合意された計測に関する品質システム ISO 17025 を満たす標準供紷が開始された.

工業標準化の進展として，固体材料の熱拡散率計測技術とし て広く用いられているレーザフラッシュ法に関する 2 件の JIS 規格「金属のレーザフラッシュ法による熱拡散率計測法」と 「セラミックス複合材のレーザフラッシュ法による熱拡散率計 測法」が成立するとともに, ISO 規格「ファインセラミックス
のレーザフラッシュ法による熱拡散率計測法」が成立した．

産業技術総合研究所が中心となって開発している「分散型熱 物性データベース」へ薄膜・界面の熱物性データ, 高温材料・ 原子力用材料，高温融体などのデータが収録されるとともに， インターネットエクスプローラなどのブラウザによりデータ ベースが利用できるようになったため，多くのユーザにより利 用された。

[馬場 哲也 (独) 産業技術総合研究所]

\section{165 伝熱}

本稿の執筆方針を決めるに際して, 過去 4 年間の本闌を参考 にさせていただいた．2002 年に関する記事 ${ }^{(12)}$ は, 世界各国の 伝熱関連学会の調査であって他とは異なる切り口であったが, 他の 3 年分は, 詳細はもちろん異なるものの, キーワードに関 してはほぼ共通していたと思われる，4年程度では大きな流れ はそれほど変わるものではないから，これは当然の結果であ り，このことは 2004 年についても同様である。

そこで本稿では，伝熱の発展を永続的に記録する論文集に焦 点を合わせて, 最新の状況を調べてみた. 折しも, 本会では論 文集発行形態の検討が 2003 年から精力的に行われており, 本 稿が発行される 2005 年 8 月には, JSME International Journal の 電子ジャーナルへの先行移行が, 熱工学部門と流体工学部門 で，すでに何らかの形で進んでいる予定である.

伝熱に強く関係すると考えられる代表的な論文集を取り上 げ，2004年に発行された号数や論文数をまとめたのが表 1 であ る。(論文数の数え方としては, 編集者からのまえがきなどは 含めず，また種々の分野から構成される論文集は筆者の独断で 数えたので, 少なからぬ任意性がある.) 同一出版社から発行 されている関連の強い論文集はひとまとめにして, 論文数の多 い順に並べた．なお，最下段二つは，他の和文論文集からの英 文化論文の再録も含むという点で, 別扱いとした。

科学出版界の巨人Elsevierの Int. J. Heat and Mass Transfer 筆頭に, 出版社と学会からおびただしい数の論文集が発行され ていることに, 今さらながら気付く. 表 1 には含めなかったが ASMEでは Journal of Heat Transfer（2005年から ASMEの中で は唯一の Monthly 化) のほかに

- Journal of Biomechanical Engineering

- Journal of Electronic Packaging

- Journal of Engineering for Gas Turbines and Power

- Journal of Fluids Engineering

- Journal of Fuel Cell Science and Technology

- Journal of Solar Energy Engineering

- Journal of Microelectromechanical Systems（IEEE と共同） などにも伝熱に基盤を打く論文が多数含まれている.また American Institute of Aeronautics and Astronautics

- AIAA Journal

- Journal of Thermophysics and Heat Transfer

にも伝熱に関する論文は少なくない。さらに，ナノの領域の研 究者は機械工学に限定されない分野の論文集に投稿しているで あろう。表 1 に示した日本伝熱学会の英文論文誌 Thermal Science and Engineering に加え, 表 1 には含めなかったもの の, 日本混相流学会, 日本熱物性学会, 日本流体力学会, 日本 燃焼学会, 日本ガスタービン学会などの会誌の中にも，数は多 くないが論文が掲載されている。 なお, 表 1 に取り上げた中で は, Microscale Thermophysical Engineering は, 論文数は決し て多くないが, scope が比較的絞られているという点で存在感 があるといえよう。

このような状況下で，まず読者の立場から考えると，大学な 
表 1 伝熱関係の代表的な論文集に関する統計（2004 年 1～12 月）

\begin{tabular}{|c|c|c|c|c|}
\hline 雑 & 誌 & 号数 & 論文数 & 考（）内は出版社 \\
\hline \multicolumn{2}{|c|}{$\begin{array}{l}\text { Int. J. of Heat and Mass Transfer } \\
\text { Int. Comm. in Heat and Mass Transfer }\end{array}$} & $\begin{array}{r}26 \\
8\end{array}$ & $\begin{array}{l}488 \\
119\end{array}$ & Full Paper と Technical Note の関係（Elsevier） \\
\hline \multirow{2}{*}{ Numerical Heat Transfer } & Part A : Applications & 20 & 103 & 年間に 2 巻 \\
\hline & Part B : Fundamentals & 12 & 56 & 年間に 2 巻（Taylor\&Francis） \\
\hline \multirow{2}{*}{\multicolumn{2}{|c|}{$\begin{array}{l}\text { Experimental Heat Transfer } \\
\text { J. of Heat Transfer }\end{array}$}} & 4 & 18 & 年間に 1 巻 \\
\hline & & 6 & 131 & 数に Technical Note を含み Photogallery は除く \\
\hline \multicolumn{2}{|c|}{ Heat and Mass Transfer } & 12 & 111 & (Springer) \\
\hline \multicolumn{2}{|c|}{ Experimental Thermal and Fluid Science } & 8 & 97 & (Elsevier) \\
\hline \multicolumn{2}{|c|}{ Int. J. of Heat and Fluid Flow } & 6 & 94 & (Elsevier) \\
\hline \multicolumn{2}{|c|}{ 日本機械学会論文集 B 編 } & 12 & 90 & 数に流体・燃焼を主に関係するものは除く \\
\hline \multicolumn{2}{|l|}{ Int. J. Multiphase Flow } & 12 & 73 & (Elsevier) \\
\hline \multicolumn{2}{|c|}{ Heat Transfer Engineering } & 7 & 56 & (Taylor\&Francis) \\
\hline \multicolumn{2}{|c|}{ Microscale Thermophysical Engineering } & 4 & 28 & (Taylor\&Francis) \\
\hline \multicolumn{2}{|c|}{ Int. J. of Transport Phenomena } & 4 & 25 & (Old City Pub.) \\
\hline \multicolumn{2}{|c|}{ Thermal Science and Engineering } & 6 & 24 & 数に伝熱シンポの Extended Abstracts は除く \\
\hline \multicolumn{2}{|c|}{$\begin{array}{l}\text { JSME International Journal Series B } \\
\text { Heat Transfer-Asian Research }\end{array}$} & $\begin{array}{l}4 \\
8\end{array}$ & - & $\begin{array}{l}\text { 再録論文・特集論文が混在（カウント困難） } \\
\text { 再録論文（ｉlev） }\end{array}$ \\
\hline
\end{tabular}

どの研究機関に所属しているものにとっては，高価な購読料を 支払った見返りとして，ほとんどの論文は自分のパソコン上か ら極めて安易にダウンロードできる。しかし多忙な（とりわけ シニアの）研究者が恒常的に目を通すことができる論文集，学 会誌は，限られているであろう。一方，著者の立場から考える と, 投稿先の選択は, scopeの適性，(是非についてはここでは 問わないとして）インパクト・ファクター，投稿料，掲載まで の予想時間など，手塩にかけて育てた研究を形として残す以 上，真剣な検討が行われることは言うまでもない.

このように考えると，とりわ忛言語的に不利を伴うことが否 定できない日本の伝熱研究者が，単に研究に専念するだけでな く，それらを記録し世界に情報を発信していく論文集について も抜本的な改革を行っていく時期が来ていることは，いうまで もないであろう。現時点の最重要課題として, 関係各位からの 積極的な提案と議論の深化，そして果敢な行動が期待される。

〔吉田 英生 京都大学〕

\section{9-1) 熱交換器}

熱交換器に関して，2004 年国内外の機械系熱工学全般を扱 う雑誌に掲載された論文を利用分野によって表 2 に分類した。 分類したのは熱交換器とこれを直接の対象とした伝熱事象に関 する論文である。そして，参考に隔年に開催されるため 2004 年には開催されなかったが，2003 年に開催された小型熱交換 器に関する国際会議 ${ }^{(13)}$ での発表件数も最右闌に載せている.

研究開発傾向をつかむため通常このような手法がとられる

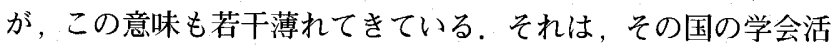
動に関係している. 日本では，熱交換器が適用される特定分野 としての空調・冷凍や自動車などの個別学会での講演や雑誌掲 載が增えている.また電子機器の冷却関連でも日本にはその分 野を担当する独自団体はないが，アメリカでは，IEEEや ASME が国際会議を隔年で交互に開催し，論文誌も用意してお

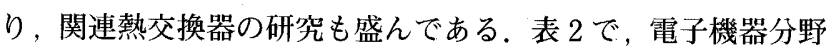
の国外での件数が少ない理由のひとつである．しかしながら， 表 2 により，実際の研究動向が全然つかめないということはな いであろう。

まず，国内の場合，表 2 を一見すれば，化学工業などの製造 プロセスや発電といった熱交換器の研究開発を支えてきた分野
表 2 熱交換器の利用分野による論文数

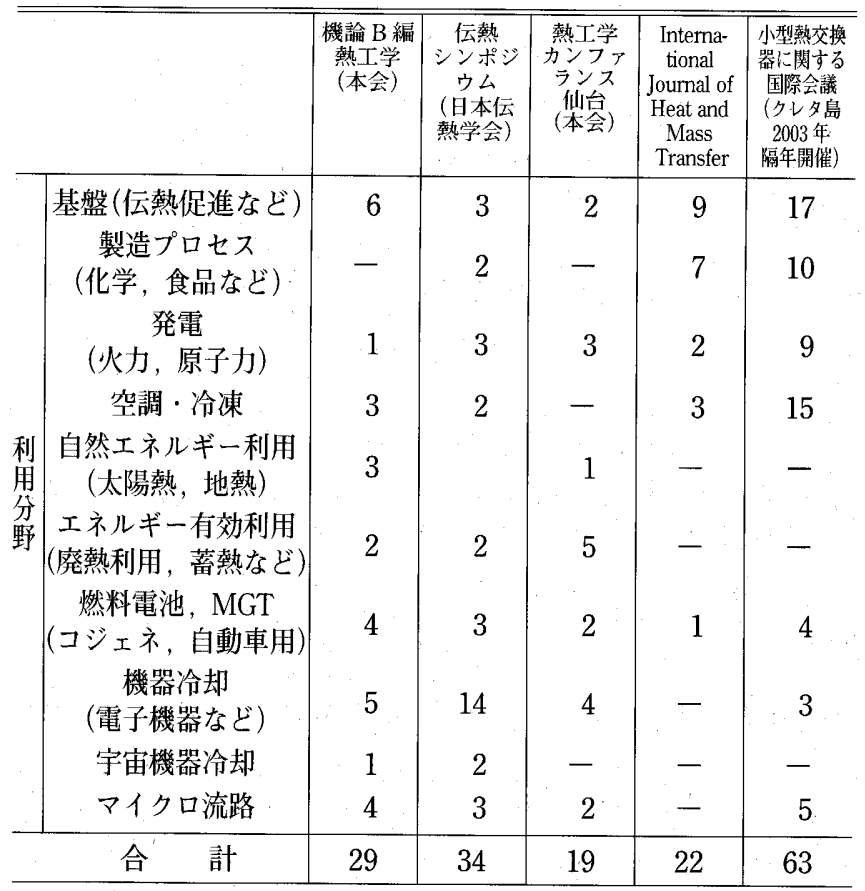

の論文が少ないこと，コジェネを含めたエネルギー有効利用， 電子機器冷却やマイクロ流路といった分野の論文の多いことが わかる，具体的には，基盤分野では伝熱促進関連が多く，渦発 生体や振動流に関するもののほかフィン付伝熱管群や自動車用 エンジンの廃熱利用も見受けられる。発電でもマイクロガス タービンといったマイクロをキーワードにした発表が目につ く. 最近多くなった電子機器分野では, システムからの放熱の ほか発熱素子の冷却にマイクロ流路からの沸騰や相変化など, マイクロ研究の応用先としても定着してきた感がある。さらに マイクロ流路は燃料電池の点発器などにも適用され, 熱交換器 の小型化を推進している。マイクロガスタービンを想定した斜 め波状壁熱交換器などは目新しい。ここ数年来, 空調用の熱交 換器の伝熱性能はすでに熟しているともいわれており，従来型 の現象発見・解明形の伝熱研究の範ちゅうでは，発表ネタが少 